\title{
IMPLEMENTASI FRAMEWORK FLUTTER UNTUK PENGADUAN MAHASISWA UNIVERSITAS XYZ
}

\section{IMPLEMENTATION OF THE FLUTTER FRAMEWORK FOR COMPLAINTS XYZ UNIVERSITY STUDENTS}

\author{
Angghy Nur Septian ${ }^{1}$ \\ 'Mahasiswa Program Studi Informatika, Fakultas Teknik dan Ilmu Komputer, Universitas Teknokrat \\ Indonesia \\ E-mail: angghynurseptian@gmail.com
}

Dikirim 10 September 2021, Direvisi 15 Oktober 2021, Disetujui 29 November 2021

\begin{abstract}
Abstrak: Pengaduan mahasiswa adalah sebuah proses untuk menyampaikan informasi atau keluhan yang dirasakan oleh mahasiswa dan disampaikan oleh mahasiswa terhadap pelayanan akademis kampus yang kinerjanya kurang memuaskan. Pengaduan mahasiswa sangat dibutuhkan pada sebuah universitas untuk memperbaiki dan meningkatkan kinerja dan kualitas universitas. Pada Universitas XYZ ini belum terdapat sistem untuk mahasiswa dalam menyampaikan keluhan-keluhan, setiap semester mahasiswa hanya mengisi kuisioner yang sudah disediakan oleh pihak kampus, namun masih ada mahasiswa yang kurang puas dengan isi kuisioner tersebut. Solusi untuk permasalahan ini adalah dengan dibuatkannya sebuah sistem menggunakan sebuah framework yaitu flutter, yang nantinya dapat digunakan oleh mahasiswa dalam menyampaikan keluhan dengan mudah, dan dapat menyampaikan keluhan tersebut kapan saja. Pihak kampus juga dapat menjadikan keluhan-keluhan yang sudah disampaikan sebagai bahan evaluasi agar menjadi lebih baik lagi.
\end{abstract}

Kata Kunci : Framework Flutter, Universitas XYZ, Pengaduan Mahasiswa,WEB, Sistem Pengaduan.

\begin{abstract}
Student complaints are a process for conveying information or complaints that are felt by students and submitted by students about campus academic services whose performance is unsatisfactory. Student complaints are needed in a university to improve and improve the performance and quality of the university. At XYZ University there is no system for students to submit complaints, every semester students only fill out a questionnaire that has been provided by the campus, but there are still students who are not satisfied with the contents of the questionnaire. The solution to this problem is to create a system using a framework, namely flutter, which later can be used by students to submit complaints easily, and can submit these complaints at any time. The campus can also make complaints that have been submitted as evaluation materials to make it even better.
\end{abstract}

Keywords: Flutter Framework, XYZ University, Student Complaints, WEB, Complaints System.

\section{PENDAHULUAN}

Teknologi Informasi dan Komunikasi (TIK) telah mengalami perkembangan yang pesat, sehingga dapat menyebabkan terjadinya berbagai perubahan dari segala bidang( (At Thaariq, 2021).

Teknologi Informasi dan Komunikasi sangat berperan penting dalam mendukung dan meningkatkan efisiensi dalam mengelola kegiatan sehari-hari, serta dapat memungkinkan pekerjaan yang dilakukan darimana saja (Utami, Sofyan, \& Pribadi, 2021).

Pengaduan mahasiswa merupakan sebuah proses untuk menyampaikan informasi ataupun keluhan-keluhan yang dirasakan oleh mahasiswa dan disampaikan oleh mahasiswa terhadap pelayanan akademis kampus yang kinerjanya kurang memuaskan. Pengaduan mahasiswa sangat dibutuhkan pada sebuah universitas untuk memperbaiki dan meningkatkan kinerja dan kualitas universitas tersebut.

Universitas XYZ merupakan salah satu kampus yang berada di Provinsi Lampung. Pada universitas XYZ ini, setiap akhir semester membagikan kuisioner untuk menilai pelayanan yang ada di universitas XYZ tersebut, guna mengevaluasi kinerja dan memperbaiki kinerja pada bagian pelayanan. Namun, masih saja terdapat mahasiswa yang kurang puas dengan isi kuisioner dan ingin menyampaikan keluhan 
atau melakukan pengaduan, namun belum ada wadah untuk menampung keluhan dari mahasiswa yang mana keluhan dari mahasiswa ini sangat berguna untuk meningkatkan kualitas dari universitas XYZ tersebut, dari permasalahan tersebut maka yang perlu ditingkatkan lagi adalah kualitas layanan akademik mahasiswa yang terdiri dari BAAK administrasi dan BAAK pelayanan yang terdapat pada Fakultas Teknik dan Ilmu Komputer (FTIK).

BAAK administrasi merupakan suatu biro kampus yang bertugas untuk melayani mahasiswa dalam hal akademik seperti NPM, KTM, nilai, transkip sementara, sidang (PKL, skripsi, proposal dan tugas akhir), yudisim, wisuda, ijazah, transkip dan sertifikat. Sedangkan untuk BAAK pelayanan bertugas untuk melayani (KRS, Jadwal dan konversi), surat menyurat, legalisir dan pengajuan judul. Namun, dalam menjalankan tugasnya BAAK sering menerima keluhan-keluhan dari mahasiswa karena kurang maksimalnya pelayanan terutama untuk BAAK administrasi pada saat penginputan KRS diawal semester.

Pada universitas XYZ biasanya pada setiap akhir semester disediakan kuisioner untuk menilai kinerja baik BAAK administrasi maupun BAAK pelayanan, namun kuisioner ini tidak dapat menampung aspirasi-aspirasi dan keluhankeluhan mahasiswa. Maka penulis membuatkan sistem bersifat dinamis untuk memfasilitasi mahasiswa yang ingin menyampaikan keluhan ataupun melakukan pengaduan terhadap BAAK administrasi dan BAAK pelayanan. Tidak hanya sebagai wadah saja, nantinya sistem ini juga bisa mengklasifikasikan pengaduan tersebut masuk ke dalam pengaduan pada BAAK administrasi ataukah pada BAAK pelayanan. Dalam pembuatan sistem tersebut penulis menggunakan framework flutter, flutter merupakan salah satu framework yang diciptakan oleh Google yang dapat digunakan pada Android dan IOS. Untuk pengklasifikasian pada jenis- jenis pengaduan penulis menggunakan sebuah algoritma klasifikasi yaitu Algoritma Naïve Bayes.

Berdasarkan pemaparan diatas, penulis membuatkan sebuah sistem berbasis web untuk memfasilitasi mahasiswa untuk menyampaikan keluhan atau pengaduan terhadap BAAK pelayanan. Jadi penelitian ini dibuat dengan tujuan untuk membantu mahasiswa yang ingin menyampaikan keluhan ataupun pengaduan terhadap BAAK administrasi dan BAAK pelayanan pada universitas XYZ, sehingga mahasiswa dapat menyampaikan keluhan ataupun pengaduan diluar dari pernyataanpernyataan yang terdapat di dalam kuisioner. Maka dengan ini, peneliti mengangkat sebuah judul "Implementasi Framework Flutter untuk Pengaduan Mahasiswa Universitas XYZ" sebagai wadah atau sarana untuk mahasiswa menyampaikan keluhan atau pengaduan, kritk dan saran terhadap BAAK administrasi dan BAAK pelayanan.

\section{METODOLOGI}

\section{Flutter}

Flutter merupakan salah satu framework atau SDK yang dibuat dan dikembangkan oleh Google untuk pengembangan aplikasi mobile. Framework flutter ini dapat digunakan dalam membuat dan mengembangkan sebuah aplikasi mobile yang bisa dijalankan menggunakan android dan ios. Bahasa yang digunakan pada framework flutter ini bermacam-macam misalnya seperti $\mathrm{C}, \mathrm{C}++$, Dart, dan Skia. Dengan tanpa adanya intrepeter pada proses compile, membuat proses compile menjadi lebih cepat karena semua kode di compile dalam kode native. Pada flutter terdapat dua widget yang mempunyai peran sebagai container dari seluruh layar, dua widget tersebut ialah stateful widget dan stateless widget.

Stateful widget merupakan sebuah widget pada flutter yang bersifat dinamis atau berubah-ubah, yang dimaksud dari 
berubah-ubah disini adalah pada saat pengguna menggunakan aplikasi ini komponen pada stateful widget ini berubahubah secara dinamis.

Stateless widget merupakan kebalikan dari stateful widget, yang mana widget ini bersifat statis atau tidak dapat diubah-ubah, karena biasanya widget ini digunakan untuk komponen sekunder yang terdapat pada stateful widget yang dibuat pengguna yang berisi sebuah komponen kustomisasi.

\section{Dart}

Menurut (Raharjo, 2019), dart adalah sebuah bahasa yang diproduksi oleh Google, yang dirancang oleh Lars Bak dan Kasper Lund, dan diperkenalkan pada 10 Oktober 2011. Dart dapat digunakan untuk membuat sebuah aplikasi server (berbentuk command-line interfaces), web, maupun mobile. Dart dapat digunakan dibeberapa platform salah satunya yaitu flutter yang menjadi framework utama yang digunakan oleh penulis untuk membuat sistem.

\section{Metode Extreme Programming (XP)}

Extreme Programming adalah metodologi pengembangan perangkat lunak yang ditujukan untuk meningkatkan kualitas perangkat lunak dan tanggap terhadap perubahan kebutuhan pelanggan. Jenis pengembangan perangkat lunak semacam ini dimaksudkan untuk meningkatkan produktivitas dan memperkenalkan pro pemeriksaan dimana persyaratan pelanggan baru dapat diadopsi (Pressman, 2009).

\section{Algoritma Nä̈ve Bayes Classifier}

Menurut (Widianto, 2019), Nä̈ve Bayes Classifier adalah sebuah metode klasifikasi yang berakar pada teorema Bayes. Metode pengklasifikasian yang menggunakan probabilitas dan statistika ini dikemukakan oleh ilmuwan Inggris Thomas Bayes, dengan berdasarkan prediksi peluang di masa yang akan datang berdasarkan pengalaman di masa yang sebelumnya itulah yang dinamakan Teorema Bayes. Keuntungan menggunakan metode ini adalah pada banyaknya data, jumlah data yang kecil menentukan perkiraan parameter yang diperlukan pada proses pengklasifikasian.

Metode bayesian classifier menggunkan pendekatan teori peluang untuk melakukan klasifikasi. Acuan yang digunakan dalam metode ini adalah Teorema Bayes. Dimana teorema bayes`menjelaskan mengenai suatu peluang kejadian berdasarkan kombinasi antara pengetahuan sebelumnya tentang kejadian tersebut dan bukti-bukti baru yang dikumpulkan dari data. Dimana secara sitematis Teorema Bayes dapat diekspresikan sebagai berikut:

$$
P(A \mid B)=\frac{P(A) P(B \mid A)}{P(B)}
$$

Keterangan :

$P(A \mid B)=$ peluang terjadinya kejadian $\mathrm{A}$ dengan syarat kejadian $B$ telah terjadi.

$P(B \mid A)=$ peluang terjadinya kejadian $\mathrm{B}$ dengan syarat kejadian telah terjadi.

$P(A)=$ peluang terjadinya kejadian $\mathrm{A}$, tanpa pengaruh kejadian yang lain.

$P(B)=$ peluang terjadinya kejadian $\mathrm{B}$, tanpa pengaruh kejadian yang lain.

Persamaan teorema bayes diatas dapat digunakan untuk melakukan klasifikasi. Pada permasalahan klasifikasi, variabel B pada persamaan Teorema Bayes menyatakan sekumpulan variabel-variabel pada data A, sedangkan A menyatakan kelas pada data.

Selama proses pelatihan, probabilitas $P(A \mid B)$ dicermati dari setiap kombinasi A dan $B$ dari data latih. Berdasarkan nilai probabilitas posterior data diklasifikasikan kedalam kelas yang memiliki nilai probabilitas Posterior $P(A \mid B)$ tertinggi. 
Terdapat tahapan-tahapan pada saat memproses algoritma Nä̈ve Bayes Classifier, sebagai berikut :

1. Menghitung jumlah kelas atau label.

2. Menghitung jumlah kasus per kelas.

3. Kalikan semua variabel kelas.

4. Bandingkan hasil per kelas.

\section{Tahapan Penelitian}

Tahapan penelitian adalah sebuah langkah yang dilakukan peneliti dalam melaksanakan penelitian. Berikut dibawah ini merupakan tahapan-tahapan penelitian yang dilakukan oleh penulis :

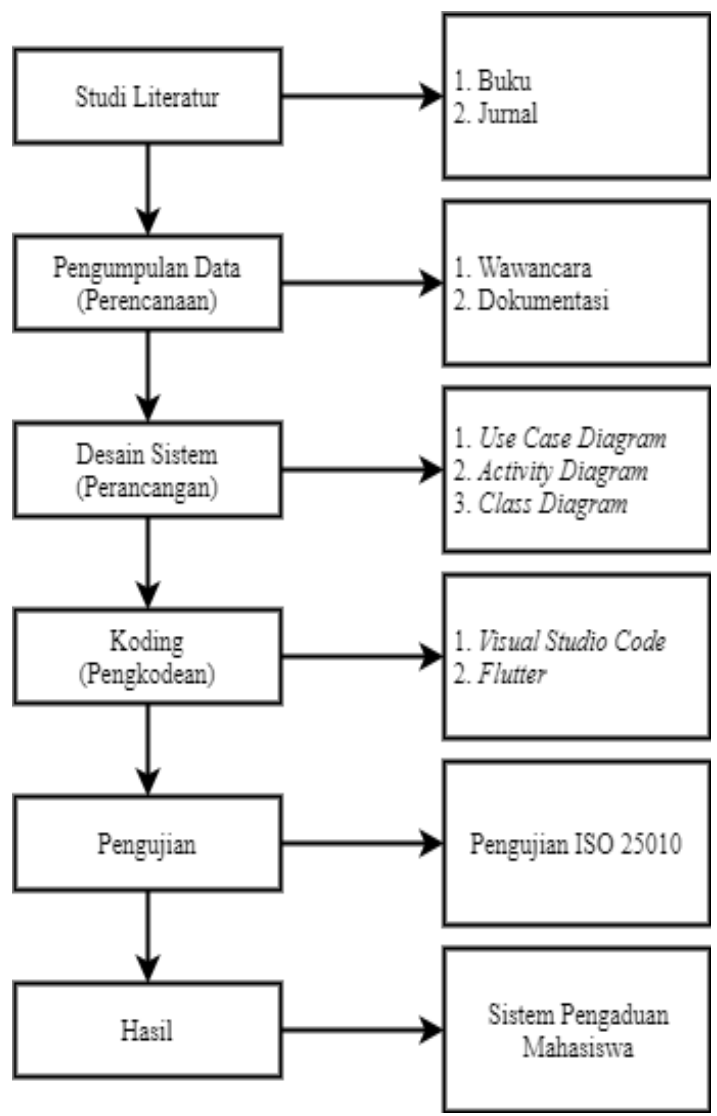

Gambar 1. proses pengembangan sistem menggunakan empat tahapan

1. Perencanaan (Planning)

Di tahapan ini penulis melakukan wawancara untuk mengetahui apa yang dibutuhkan oleh pengguna, dan mengetahui masalah yang dialami oleh pengguna.

2. Perancangan (Desain)

Di tahapan ini penulis sudah mulai merancang apa yang sudah direncanakan dan perancangan ini menggunakan sebuah metode yaitu UML.

3. Koding (Coding)

Di tahap ini penulis sudah mulai mengimplementasikan rancanganrancangan yang sudah dibuat.

4. Pengujian (Testing)

Tahapan ini merupakan tahapan terakhir yang dilakukan oleh penulis yaitu pengujian, dimana tahapan ini dilakukan dengan menguji sistem yang sudah selesai dikerjakan.

\section{Algoritma Nä̈ve Bayes Classifier}

Algoritma ini merupakan algoritma yang banyak dipakai untuk pengklasifikasian sebuah data. Pada penelitian yang akan diteliti, menggunakan sebuah metode pengklasifikasian untuk mengklasifikasian keluhan-keluhan yang diajukan oleh mahasiswa. Algoritma ini digunakan untuk pengklasifikasian jenis keluhan yang nantinya berguna untuk penanganan selanjutnya. Berikut adalah tahapan-tahapan pada algoritma Nä̈ve Bayes Classifier:

1. Menghitung jumlah kelas atau label, hitung terlebih dahulu kelas atau label yang ada pada sistem tersebut.

2. Menghitung jumlah kasus per kelas, kemudian hitung jumlah kasus di masing-masing kelasnya.

3. Kalikan semua variabel kelas, ketika semuanya selesai kalikan semua variabel kelas untuk mencari hasilnya.

4. Bandingkan hasil per kelas, setelah dikalikan maka bandingkanlah semua hasil perkalian yang sudah dikalikan tadi. 
Dimana secara sitematis Teorema Bayes dapat diekspresikan sebagai berikut:

$$
P(A \mid B)=\frac{P(A) P(B \mid A)}{P(B)}
$$

Keterangan :

$P(A \mid B)=$ peluang terjadinya kejadian $\mathrm{A}$ dengan syarat kejadian $B$ telah terjadi.

$P(B \mid A)=$ peluang terjadinya kejadian $\mathrm{B}$ dengan syarat kejadian telah terjadi.

$P(A)=$ peluang terjadinya kejadian $\mathrm{A}$, tanpa pengaruh kejadian yang lain.

$P(B)=$ peluang terjadinya kejadian $\mathrm{B}$, tanpa pengaruh kejadian yang lain.

\section{Pengujian ISO 25010}

Menurut (Wattiheluw, 2019), pengujian ISO 25010 merupakan bagian dari Systems and Software Quality Requirements and Evaluation (SQuaRE) yang merupakan versi lanjutan dari ISO 91261, yang telah direvisi secara teknis dengan menambahkan beberapa struktur dan bagian dari standar model kualitas. Tujuan dari penggunaan kualitas ini adalag untuk mengukur sejauh mana produk atau sistem tersebut bisa digunakan oleh pengguna untuk memenuhi kebutuhan dalam mencapai tujuan yang diinginkan dengan efisiensi, efektivitas, kepuasan dalam konteks penggunaan yang spesifik, dan bebas dari resiko.

Menurut (Harun, 2018), ISO 25010 terdiri dari delapan karakteristik yang dibagi menjadi beberapa bagian yang berhubungan dengan sifat-sifat statis perangkat lunak dan sifat dinamis dari sistem komputer, yang dapat ditunjukkan pada gambar dibawah ini :

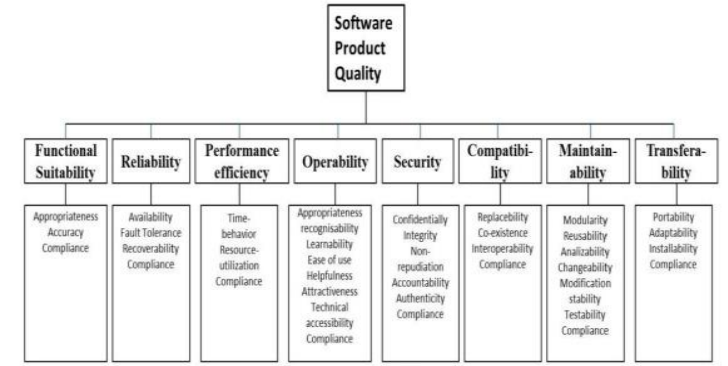

Gambar 2. Delapan karakteristik sifat-sifat statis perangkat lunak dan sifat dinamis dari sistem komputer

Berdasarkan gambar diatas, dapat dijelaskan mengenai delapan karakteristik tersebut, sebagai berikut :

1. Functional Suitability, merupakan sistem atau produk yang memberikan fungsional untuk memenuhi kebutuhan saat sistem atau produk tersebut digunakan pada keadaan tertentu.

2. Reliability, merupakan tingkat dimana suatu sistem atau produk dapat mempertahankan kinerjanya pada level tertentu ketika digunakan pada keadaan tertentu.

3. Performance Efficiency, merupakan tingkat dimana sistem atau produk menyediakan performa yang baik dengan sejumlah resource yang akan digunakan pada sistem atau produk.

4. Usability, merupakan tingkat dimana pada suatu sistem atau produk mudah dimengerti, mudah dipakai, dan menarik untuk digunakan.

5. Security, merupakan tingkat dimana pada suatu sistem atau produk menyediakan layanan untuk melindungi akses, penggunaan, modifikasi, pengrusakan, ataupun pengungkapan yang berbahaya.

6. Compatibality, merupakan kemampuan pada suatu komponen atau sistem untuk bertukar informasi.

7. Maintainability, merupakan tingkat dimana pada suatu sistem atau produk dapat dimodifikasi, yang 
meliputi perbaikan, pengembangan untuk menyesuaikan dengan lingkungan, modifikasi pada kriteria, dan spesifikasi fungsi.

8. Portability, merupakan tingkat dimana pada suatu sistem atau produk dapat dipindahkan dari satu ruang ke ruang lainnya.

\section{Skala Likert}

Skala likert merupakan sebuah skala yang dapat digunakan untuk mengukur pendapat, presepsi, ataupun sikap seseorang maupun sekelompok orang tentang suatu fenomenal social. Untuk mengukur sikap pada suatu objek, subjek, atau kejadian tertentu pada skala likert terdapat dua pernyataan yaitu setuju dan tidak setuju. Pada skala likert ini biasanya juga menggunakan beberapa pernyataan, misalnya seperti sangat setuju, setuju, netral, tidak setuju, dan sangat tidak setuju.

\section{PIECES}

Menurut (Ragil, 2010:17), metode PIECES merupakan sebuah metode analisis yang digunakan sebagai dasar untuk memperoleh pokok-pokok permasalahan yang lebih spesifik. Dalam menganalisis sebuah sistem, biasanya akan dilakukan terhadap beberapa aspek antara lain adalah kinerja, informasi, ekonomi, keamanan aplikasi, efisiensi, dan pelayanan pelanggan. Analisis ini disebut dengan PIECES Analisis (Performance, Infromation, Economy, Control, Eficiency, and Service).

\section{Use Case Diagram}

Use case merupakan proses kegiatan dan proses bisnis yang dilakukan oleh aktor yang saling berinteraksi antara aktor dengan use case. Pada penelitian ini penulis menggunakan dua aktor yaitu user dan admin. Gambar alur use case pada perancangan sistem pengaduan pada universitas XYZ dapat dilihat pada gambar di bawah ini.

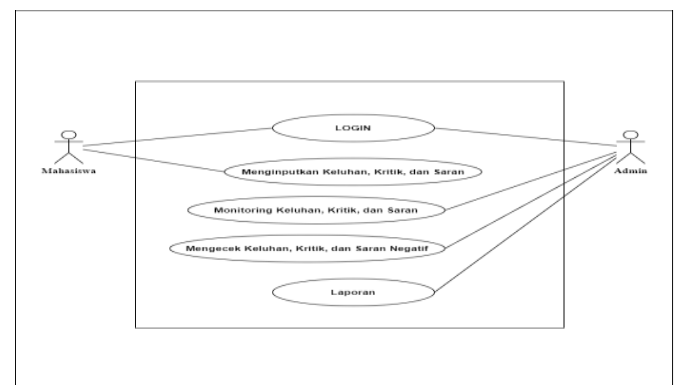

Gambar 1. Use Case Diagram

Penjelasan Use case diagram

Tabel 1. Penjelasan Use Case

\begin{tabular}{|c|c|}
\hline Aktor & Kegiatan \\
\hline Admin & $\begin{array}{l}\text { Kegiatan yang } \\
\text { dilakukan oleh } \\
\text { admin yaitu login } \\
\text { ke sistem terlebih } \\
\text { dahulu kemudian } \\
\text { admin dapat } \\
\text { memonitoring } \\
\text { keluhan, kritik dan } \\
\text { saran yang masuk } \\
\text { ke sistem, lalu } \\
\text { admin juga dapat } \\
\text { mengecek dan } \\
\text { menghapus } \\
\text { keluhan, kritik dan } \\
\text { saran yang bersifat } \\
\text { negatif. Keluhan- } \\
\text { keluhan yang } \\
\text { berhasil disaring } \\
\text { akan dicetak dalam } \\
\text { bentuk laporan } \\
\text { yang nantinya akan } \\
\text { diserahkan ke } \\
\text { pimpinan. }\end{array}$ \\
\hline User & \begin{tabular}{l}
\multicolumn{2}{c}{ Kegiatan yang } \\
dilakukan oleh user \\
yaitu login ke \\
dalam sistem \\
pengaduan dan \\
mengisikan \\
keluhan yang ingin \\
disampaikan oleh \\
user
\end{tabular} \\
\hline
\end{tabular}




\section{Activity Diagram}

Diagram aktivitas atau activity diagram merupakan gambaran aliran kerja atau aktifitas dari sebuah sistem atau proses bisnis yang ada pada perangkat lunak. Activity diagram pada rancangan sistem pengaduan pada universitas XYZ dapat dilihat pada Gambar di bawah ini:

1. Activity Diagram Login

Berikut ini merupakan alur proses login yang dilakukan oleh mahasiswa

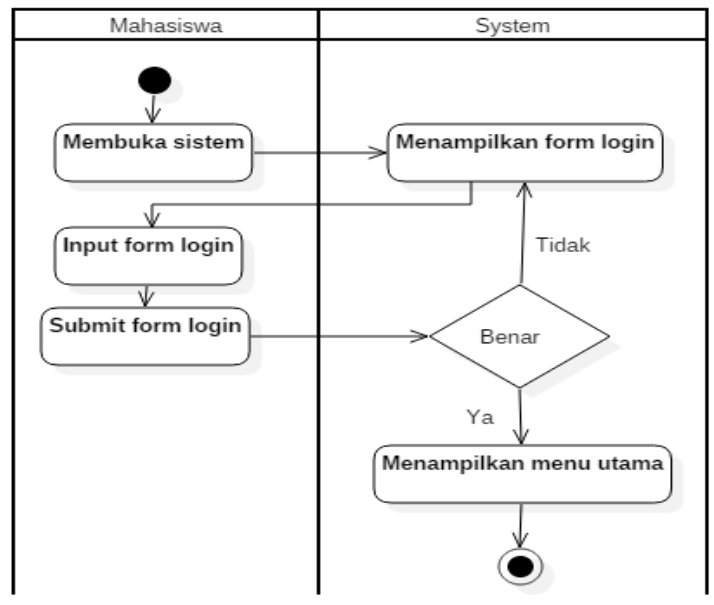

Gambar 2. Activity Diagram Login

2. Activity Diagram Membuat Pengaduan

Berikut merupakan alur pada saat mahasiswa ingin membuat pengaduan.

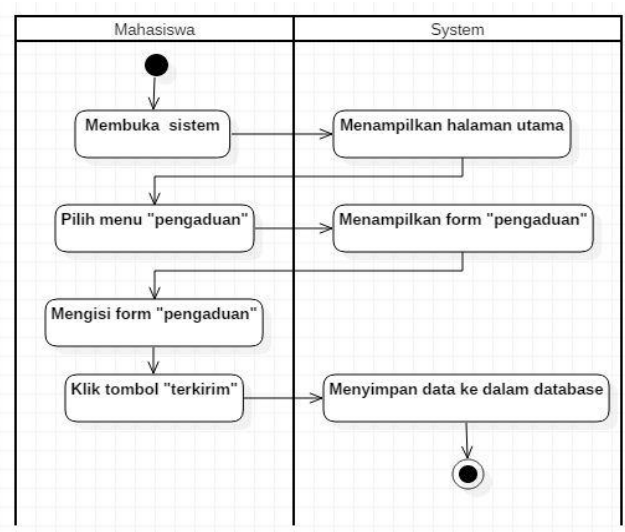

Gambar 3. Activity Diagram Membuat Pengaduan

\section{Class Diagram}

Class Diagram merupakan sebuah pemodelan yang menggambarkan suatu struktur yang terdapat pada sistem yang dilihat dari segi pendefinisian kelas-kelas yang akan dibuat. Berikut adalah Class Diagram yang ada pada penelitian ini :

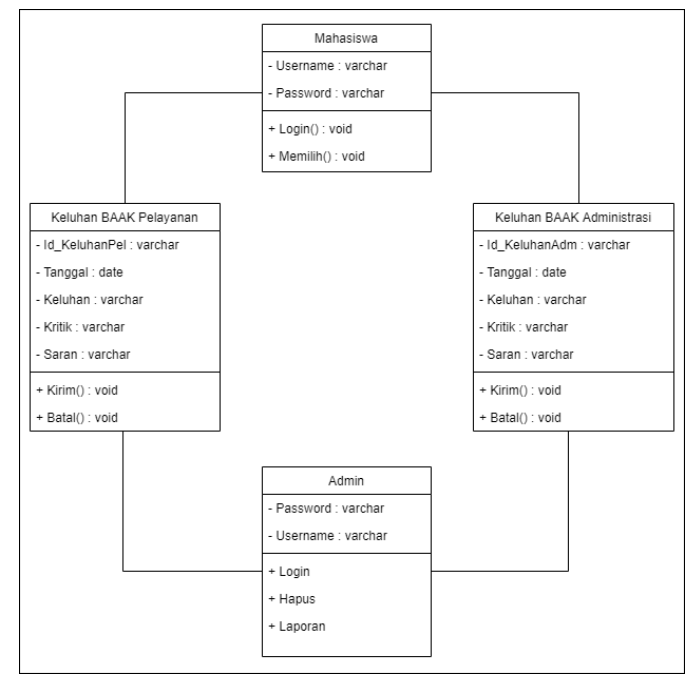

Gambar 4. Class Diagram Membuat Pengaduan

\section{Analisis PIECES}

Analisis PIECES digunakan untuk menganalisa pokok-pokok permasalahan yang lebih spesifik, analisis PIECES pada penelitian ini dapat dijelaskan sebagai berikut :

1. Performance (Kekuatan) : sistem yang berjalan saat ini masih menggunakan google form sehingga masih harus menyebarkan link Google formnya, solusi yang diberikan yaitu menyediakan sebuah sistem yang sudah terkomputerisasi sehingga memudahkan mahasiswa untuk membuat keluhan, pengaduan, kritik maupun saran.

2. Information (Informasi) :

Informasi terkait pengisian kuisioner pun hanya dishare melalui broadcast via whatsapp saja. Informasi terkait proses pengaduan dll sudah sejauh mana berjalan kurang efektif 
dikarenakan melalui Google form, solusinya adalah menyediakan sistem yang bisa memantau proses pengaduan secara cepat melalui notifikasi.

3. Economy (Ekonomi) : Untuk permasalahan ekonomi ini sama sama tidak mengeluarkan biaya yang besar, namun dalam penggunaannya sistem memiliki kelebihan yaitu di buat sekali dan digunakan untuk seterusnya

4. Control (Kontrol) :

Sistem yang digunakan saat ini masih kurang aman dalam kerahasiaan datanya, solusinya adalah sistem yang sekarang dapat menyimpan data dengan baik dan kerahasiaan data terjamin.

5. Eficiency (Efisiensi)

Keluhan, pengaduan, kritik ataupun saran hanya dapat dilakukan saat akhir semester untuk menilai seberapa baik pelayanan yang sudah berjalan, dan harus membuat Google Form setiap ingin mengadakan penilaian. Solusinya adalah dengan adanya sistem ini keluhan, pengaduan, kritik ataupun saran dapat dilakukan kapan saja tidak terbatas waktu selagi masih menjadi mahasiswa aktif perkuliahan di kampus

Service (Pelayanan) : Pelayanan yang diberikan tidak bisa diketahui oleh mahasiswa apakah keluhan di proses atau tidak, solusinya adalah menyediakan sistem yang dapat melihat keluhan sudah diproses atau belum.

\section{HASIL DAN PEMBAHASAN}

1. Tampilan Beranda Admin

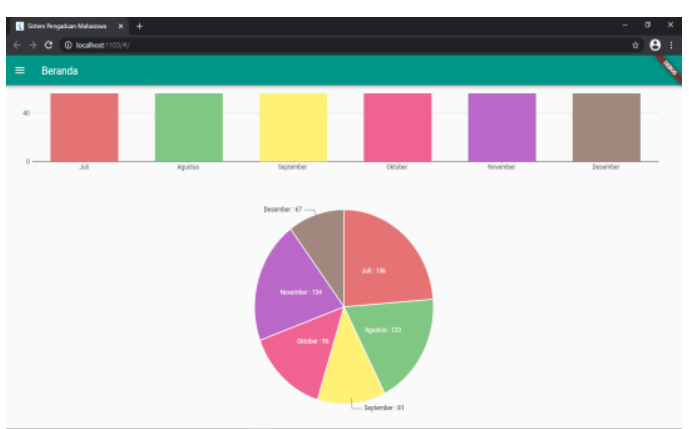

Gambar 5. Tampilan Beranda Admin

2. Tampilan Form Mahasiswa

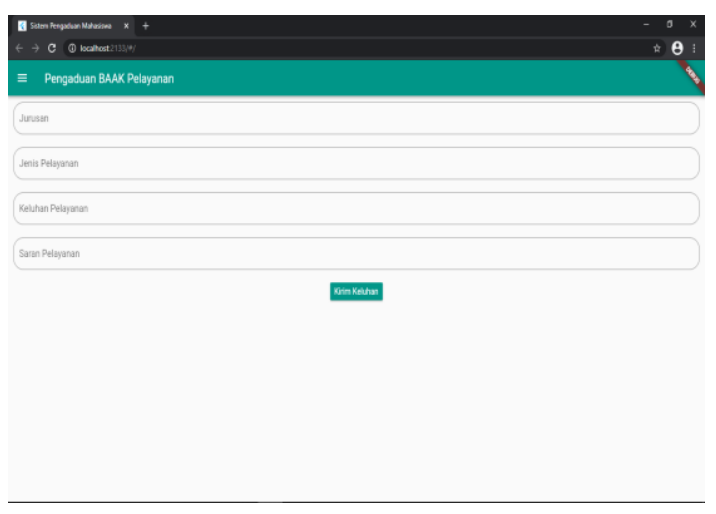

Gambar 6. Tampilan Form Mahasiswa

\section{Pengujian Aspek Functionality}

Pengujian ini melakukan pengujian pada fungsi-fungsi yang terdapat pada sistem yang telah dibuat. Berikut pengujian pada aspek functionality.

Tabel 2. Bobot Jawaban Functionality

\begin{tabular}{|l|l|l|}
\hline Jawaban & Ya & Tidak \\
\hline Bobot & 1 & 0 \\
\hline \multicolumn{2}{|c|}{ Sumber: (Sugiyono, 2018) }
\end{tabular}

Dibawah ini merupakan kriteria penilaian klasifikasi skor :

$$
\begin{aligned}
& \text { Klasifikasi Persentase } \\
& =\frac{\text { Bobot Jawaban }}{\text { Bobot Jawaban Maksimal }} \times 100 \% \\
& \text { - Persentase nilai, Ya= } \\
& \frac{1}{1} \times 100 \%=100 \% \\
& \text { - } \text { Persentase nilai, Tidak }=\frac{0}{1} \times \\
& 100 \%=0 \%
\end{aligned}
$$


Dengan berdasarkan penjelasan diatas, dapat digambarkan menggunakan sebuah skala yaitu untuk mengetahui yang hasil dari bagian tidak atau ya, dapat digambarkan sebagai berikut.

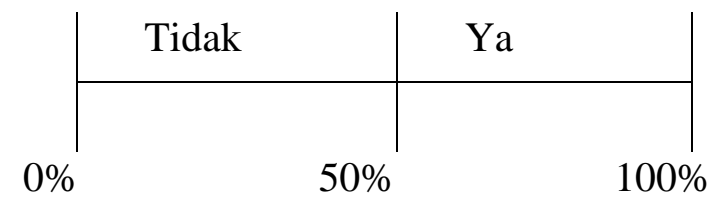

Gambar 7. Kualifikasi Skala Pengukuran Functionality

Sumber: (Sugiyono, 2018)

Tabel 3. Hasil pengujian Functionality

\begin{tabular}{|c|c|c|c|}
\hline n Pertanyaa & $a^{Y}$ & ${ }_{\mathrm{k}}{ }^{\text {Tida }}$ & ${ }_{\mathrm{r}}$ Sko \\
\hline \multicolumn{4}{|c|}{ Functional Completeness } \\
\hline $\begin{array}{l}\text { Apakah } \\
\text { sistem ini } \\
\text { dapat } \\
\text { menampilkan } \\
\text { rekapan } \\
\text { bulanan? }\end{array}$ & 5 & & 5 \\
\hline $\begin{array}{l}\text { Apakah } \\
\text { sistem ini } \\
\text { dapat } \\
\text { mengolah } \\
\text { data keluhan } \\
\text { yang telah } \\
\text { diisi? }\end{array}$ & 5 & & 5 \\
\hline \begin{tabular}{l}
\multicolumn{2}{c}{ Apakah } \\
sistem ini \\
dapat \\
menampilkan \\
tabel hasil \\
pengisian \\
formulir?
\end{tabular} & & 5 & 0 \\
\hline $\begin{array}{l}\text { Apakah } \\
\text { sistem ini } \\
\text { dapat } \\
\text { menghapus } \\
\text { data tabel? }\end{array}$ & & 5 & 0 \\
\hline $\begin{array}{l}\text { Apakah } \\
\text { sistem ini } \\
\text { dapat }\end{array}$ & & 5 & 0 \\
\hline
\end{tabular}

\begin{tabular}{|c|c|c|c|}
\hline $\begin{array}{l}\text { mencetak } \\
\text { laporan? }\end{array}$ & & & \\
\hline $\begin{array}{l}\text { Apakah } \\
\text { sistem ini } \\
\text { terkoneksi ke } \\
\text { database? }\end{array}$ & 5 & & 5 \\
\hline $\begin{array}{l}\text { Apakah } \\
\text { sistem ini } \\
\text { menampilkan } \\
\text { form untuk } \\
\text { menyampaik } \\
\text { an keluhan? }\end{array}$ & 5 & & 5 \\
\hline \multicolumn{4}{|c|}{ Functional Correctness } \\
\hline $\begin{array}{l}\text { Apakah } \\
\text { sistem ini } \\
\text { menampilkan } \\
\text { data secara } \\
\text { detail? }\end{array}$ & & 5 & 0 \\
\hline \begin{tabular}{l}
\multicolumn{2}{c}{ Apakah } \\
sistem ini \\
menampilkan \\
informasi \\
hasil rekapan \\
bulanan \\
dengan \\
menggunaka \\
n diagram?
\end{tabular} & 5 & & 5 \\
\hline \begin{tabular}{l}
\multicolumn{2}{c}{ Apakah } \\
sistem ini \\
dapat diakses \\
dengan \\
mudah?
\end{tabular} & 5 & & 5 \\
\hline \begin{tabular}{l}
\multicolumn{1}{c}{ Apakah } \\
laporan \\
sesuai dengan \\
format yang \\
diinginkan?
\end{tabular} & & 5 & 0 \\
\hline \multicolumn{4}{|c|}{ Functional Appropriatness } \\
\hline \begin{tabular}{l}
\multicolumn{1}{c}{ Apakah } \\
dengan \\
dibuatkannya \\
sistem \\
pengaduan \\
mahasiswa \\
ini dapat \\
mempermuda
\end{tabular} & 5 & & 5 \\
\hline
\end{tabular}




\begin{tabular}{|l|c|c|c|}
\hline $\begin{array}{l}\text { h admin } \\
\text { dalam } \\
\text { menerima } \\
\text { keluhan? }\end{array}$ & & \\
\hline $\begin{array}{l}\text { Apakah } \\
\text { sistem ini } \\
\text { dibuat sesuai } \\
\text { kebutuhan? }\end{array}$ & 5 & & 5 \\
\hline $\begin{array}{l}\text { Apakah ini } \\
\text { sistem } \\
\text { menyimpan } \\
\text { data sesuai } \\
\text { dengan } \\
\text { fungsinya? }\end{array}$ & 5 & & 5 \\
\hline \multicolumn{2}{|c|}{ Total } & & 45 \\
\hline
\end{tabular}

Berdasarkan dari total skor yang sudah dihitung di tabel diatas, lalu seluruhnya dihitung dengan menggunakan skala likert, sebagai berikut :

$$
\begin{aligned}
& \text { Klasifikasi Persentase } \\
& =\frac{\text { Bobot Jawaban }}{\text { Bobot Jawaban Maksimal }} \times 100 \%
\end{aligned}
$$

Klasifikasi Persentase

$$
=\frac{40}{70} \times 100 \%
$$

$$
\begin{array}{r}
\text { Klasifikasi Persentase } \\
=64,28 \%
\end{array}
$$

Berdasarkan dari perhitungan diatas, menghasilkan persentase sebesar 64,28\% yang dapat disimpulkan berdasarkan dengan kriteria persentase hasil uji, berikut tabelnya :

Tabel 4. Kriteria Persentase Hasil Uji

\begin{tabular}{|c|c|}
\hline $\begin{array}{c}\text { Jumlah Skor } \\
(\%)\end{array}$ & Kriteria \\
\hline $0-49$ & Gagal \\
\hline $50-100$ & Sukses \\
\hline
\end{tabular}

Sumber: (Sugiyono, 2018)

Berdasarkan dari tabel kriteria persentasi hasil uji yang ada diatas, dapat disimpulkan bahwa aspek Functionality
Suitability yang dinilai oleh responden "Sukses" dibuat karena memenuhi kriteria persentase hasil uji.

\section{Pengujian Aspek Usability}

Pengujian pada aspek ini, pengujiannya dilakukan dengan menggunakan kuisioner, yang diberikan kepada mahasiswa dan admin, dan dengan mencoba terlebih dahulu sistem yang telah dibuat sebelum mengisi kuisionernya. Pengujian ini terdapat 5 kategori jawaban yang berbeda dengan bobot yang berbeda juga, masing-masing jawabannya yaitu :
1. Sangat Setuju $=5$
2. Setuju $=4$

\begin{tabular}{|c|c|c|c|c|c|c|c|}
\hline z & 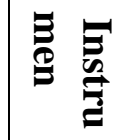 & $\mathscr{2}$ & $\boldsymbol{\omega}$ & $\tilde{\Omega}$ & $\vec{\sigma}$ & $\stackrel{\mathscr{\Omega}}{\vec{\Omega}}$ & $\frac{\mathscr{N}}{\hat{T}}$ \\
\hline \multicolumn{8}{|c|}{ Appropriateness Recognizability } \\
\hline 1. & $\begin{array}{l}\quad \mathrm{Si} \\
\text { stem } \\
\text { ini } \\
\text { mem } \\
\text { bantu } \\
\text { saya } \\
\text { menj } \\
\text { adi } \\
\text { lebih } \\
\text { muda } \\
\text { h } \\
\text { meny } \\
\text { ampa } \\
\text { ikan } \\
\text { keluh } \\
\text { an }\end{array}$ & 5 & & & & & 5 \\
\hline 2. & $\begin{array}{l}\quad \text { Si } \\
\text { stem } \\
\text { ini } \\
\text { berm } \\
\text { anfaa } \\
\mathrm{t} \\
\text { untuk }\end{array}$ & 5 & & & & & 5 \\
\hline
\end{tabular}
3. Ragu-Ragu = 3
4. Tidak Setuju $=2$
5. Sangat Tidak Setuju $=1$

Tabel 5. Hasil Pengujian Usability 


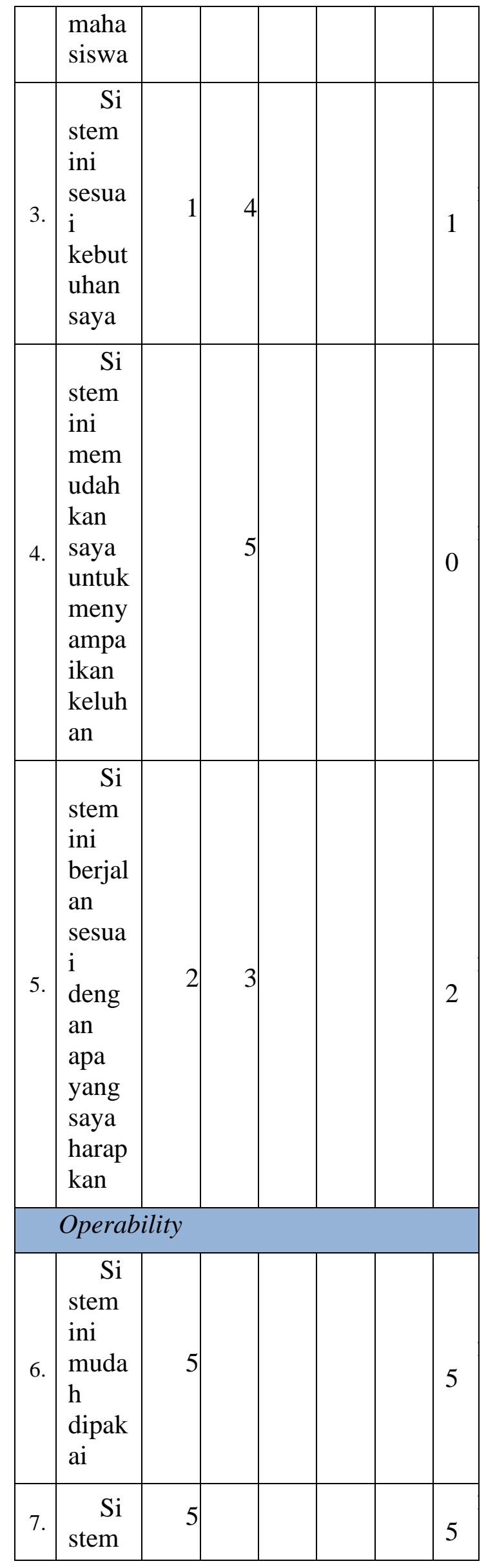

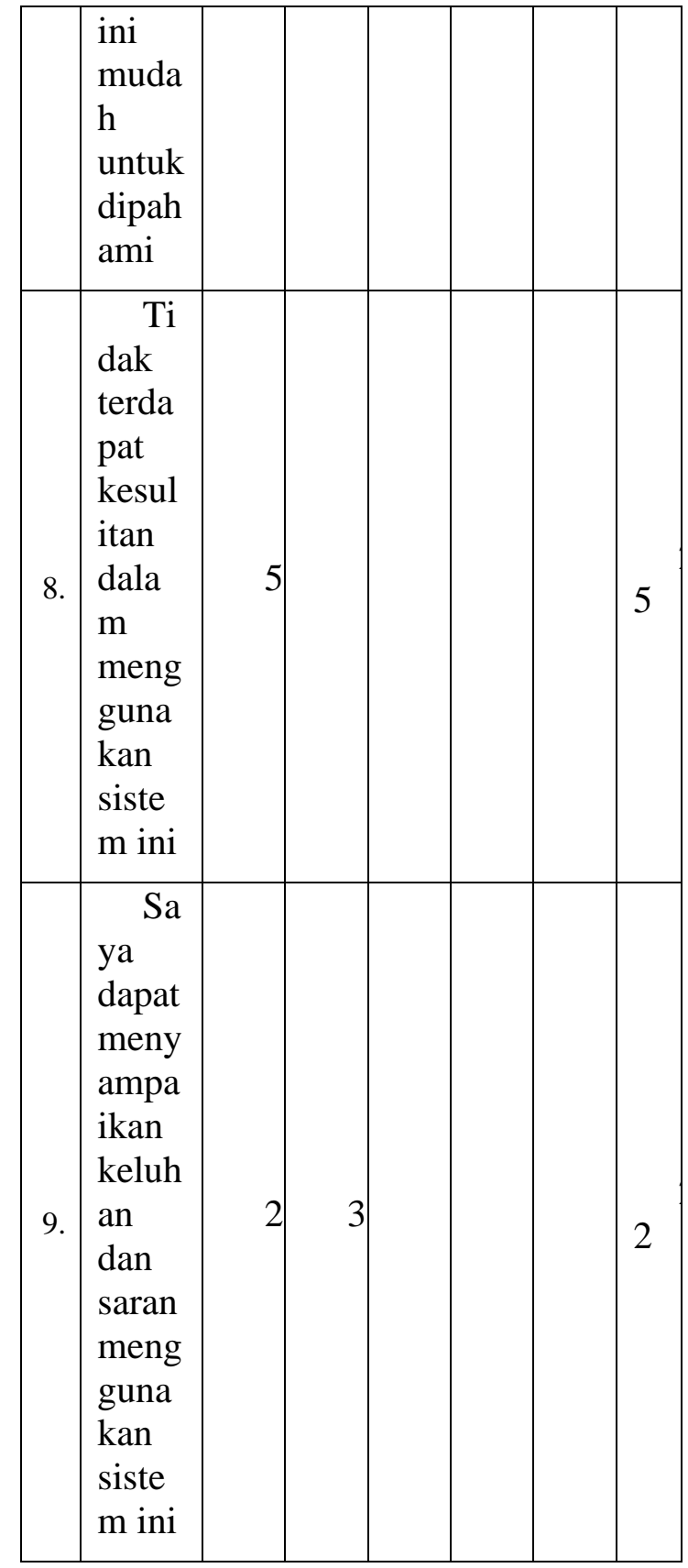

Tabel 6. Hasil Pengujian Usability (Lanjutan)

\begin{tabular}{|c|c|c|c|c|c|c|c|}
\hline Za & 急 & $\mathscr{\Omega}$ & Us & $\widetilde{\Omega}$ & $\vec{\sim}$ & $\frac{\tilde{\Omega}}{\tilde{\sigma}}$ & $\frac{\mathscr{\omega}}{\mathbb{T}}$ \\
\hline 10. & $\begin{array}{l}\quad \text { Say } \\
\text { a } \\
\text { berhas } \\
\text { il } \\
\text { meng } \\
\text { gunak } \\
\text { an } \\
\text { sistem }\end{array}$ & & & & & & 5 \\
\hline
\end{tabular}




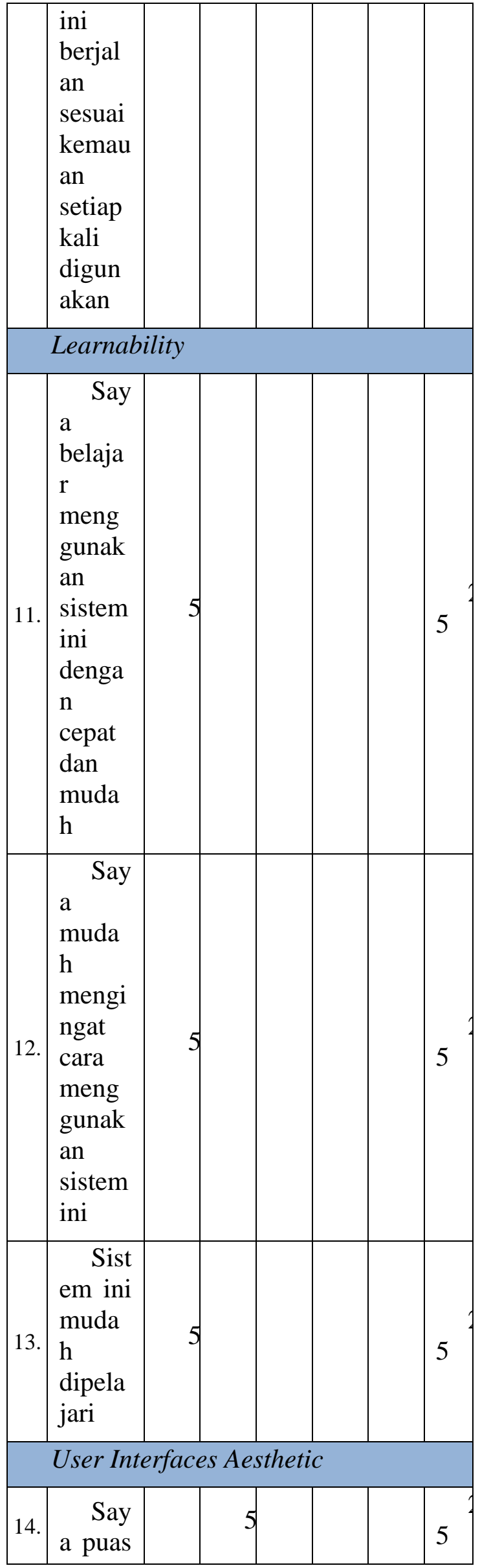

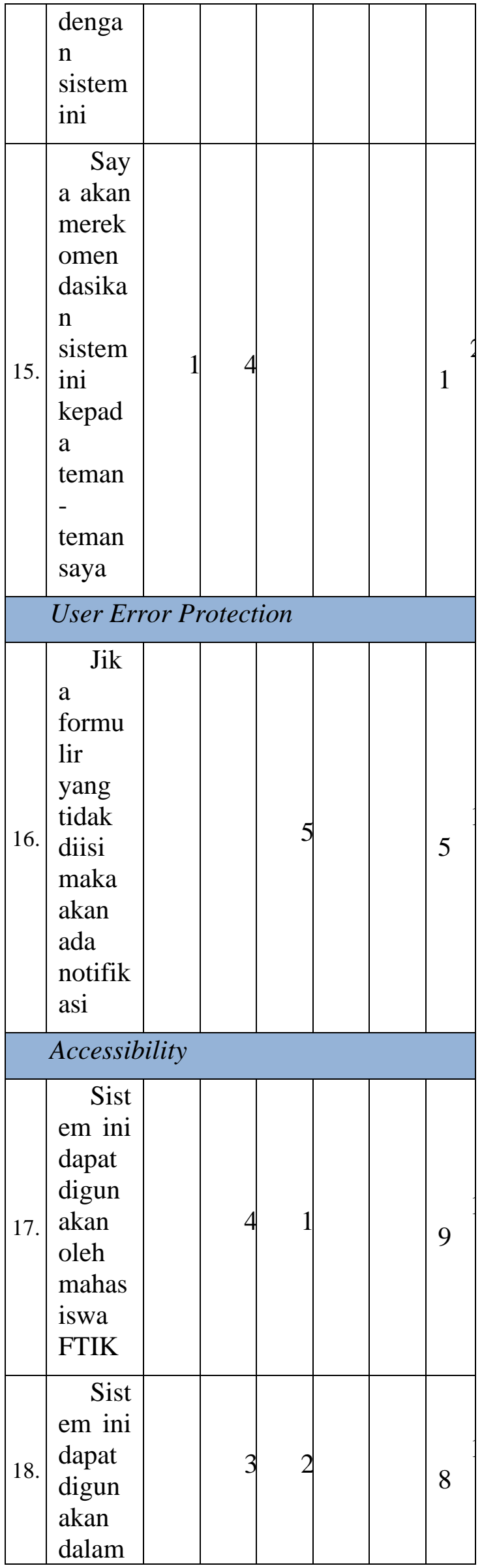




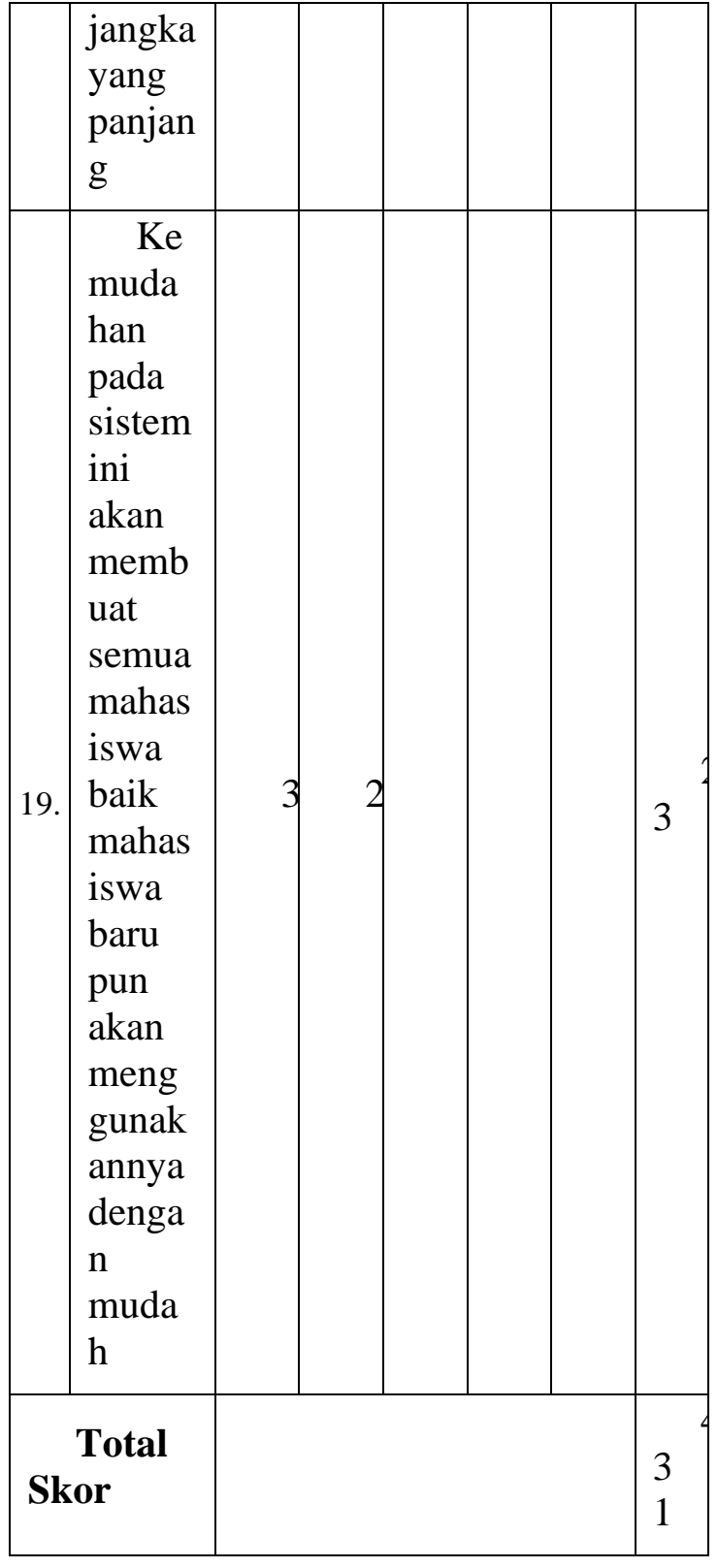

Berdasarkan dari hasil kuisioner pada pengujian usability yang telah dilakukan dapat dihitung dengan menggunakan skala likert menuru (Sugiyono, 2018). Pada kuisioner tersebut terdapat 5 bobot nilai yaitu :

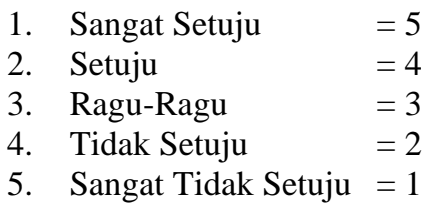

Maka, skor yang diperolah tadi akan dibagi dengan nilai tertinggi, jika ketiga responden menjawab "Sangat Setuju" yang bernilai 5 , maka hasilnya $5 \times 5=25$, lalu dikalikan dengan jumlah pernyataan sebanyak 19 sehingga mempunyai total 475 , dengan menghitungnya sebagai berikut :

$$
\begin{aligned}
\text { Hasil } & =\frac{\text { Skor Diperoleh }}{\text { Skor Maksimal }} \times 100 \% \\
\text { Hasil } & =\frac{431}{475} \times 100 \% \\
\text { Hasil } & =90,73 \%
\end{aligned}
$$

Dari hasil persentase diatas yang telah dihitung dapat dikategorikan menggunakan tabel hasil uji sistem pada aspek Usability, seperti dibawah ini :

Tabel 7. Hasil Pengukuran Persentase

\begin{tabular}{|c|c|c|}
\hline No & Nilai & Hasil \\
\hline $\mathbf{1 .}$ & $\begin{array}{c}80 \%- \\
100 \%\end{array}$ & Sangat Setuju \\
\hline $\mathbf{2 .}$ & $60 \%-79 \%$ & Setuju \\
\hline $\mathbf{3 .}$ & $40 \%-59 \%$ & Ragu-Ragu \\
\hline $\mathbf{4 .}$ & $20 \%-39 \%$ & Tidak Setuju \\
\hline $\mathbf{5 .}$ & $0 \%-19 \%$ & $\begin{array}{c}\text { Sangat Tidak } \\
\text { Setuju }\end{array}$ \\
\hline
\end{tabular}

Sumber: (Sugiyono, 2018)

Dari hasil persentase skor diatas, diperoleh skor sebesar $90,73 \%$, yang dapat disimpulkan dengan menggunakan tabel tersebut diperoleh kesimpulan bahwa responde "Sangat Setuju" bahwa sistem tersebut dibuat dengan sesuai.

\section{KESIMPULAN}

Berdasarkan dari penjelasan dari babbab yang ada diatas, penulis dapat menarik kesimpulan, sebagai berikut :

1. Pembuatan sistem pengaduan mahasiswa terhadap BAAK Pelayanan dan BAAK Administrasi pada Fakultas Teknik dan Ilmu Komputer dibuat menggunakan framework baru yaitu Flutter, dengan menggunakan bahasa Dart. Pada pembuatan sistem ini, dibuat dengan menggunakan metode 
Extreme Programming yang dapat diimplementasikan untuk pengembangan sistem yang hanya beranggotakan 1-2 orang saja, dan dengan waktu yang singkat. Sistem ini dibuat dengan tools yaitu Visual Studio Code dan $M y S q l$ sebagai penyimpanan database-nya. Sistem yang dibuat, menghasilkan sebuah sistem yang dapat digunakan mahasiswa FTIK untuk menyampaikan keluhan-keluhan terhadap BAAK Pelayanan dan BAAK Administrasi di Fakultas Teknik dan Ilmu Komputer.

2. Hasil dari pembuatan sistem ini adalah agar dapat mempermudah mahasiswa dalam menyampaikan keluhan-keluhannya sewaktuwaktu dan tidak menunggu hingga akhir semester. Hasil dari pengujian aspek Functionality Suitability diperoleh skor $64,28 \%$ yang dapat disimpulkan bahwa sistem ini sukses dibuat karena memenuhia kriteria persentase hasil uji, kemudian untuk hasil dari pengujian aspek Usability memperoleh skor $90,73 \%$ yang dapat disimpulkan bahwa sistem tersebut telah disetujui.

3. Kendala yang dihadapi penulis adalah waktu pengerjaan yang terbilang begitu singkat, dan penggunaan sebuah framework baru yaitu flutter, hingga masih adanya error pada sistem, yang terdiri dari :

- Tidak dapat menampilkan data tabel pada halaman admin yang sudah dibuat.

- Tidak dapat menghapus data pada tabel sistem.

- Tidak dapat mencetak laporan.

\section{DAFTAR PUSTAKA}

Alkadri, S. P., \& Insani, R. W. (2019). PERANCANGAN APLIKASI PELAPORAN KEKERASAN
PEREMPUAN DAN ANAK

PADA DPPA PROV KALBAR

BERBASIS ANDROID.

"Peningkatan Mutu Pendidikan

MIPA dan Teknologi di Era Revolusi Industri 4.0”.

Duke, A. F., Krisnanda, M., \& Kainde, Q. C. (2020). Sistem Lapor Dini Bencana Kebakaran Berbasis Mobile di Kota Bitung. JOINTER.

Hakim, A. R., Harefa, K., \& Widodo, B. (2019).

PENGEMBANGAN SISTEM

INFORMASI AKADEMIK BERBASIS ANDROID MENGGUNAKAN FLUTTER DI POLITEKNIK.

Iqbal, H., \& Bahar, M. (2016). An Approach for Analyzing ISO / IEC $25010 \quad$ Product Quality Requirements based on Fuzzy Logic and Likert Scale for Decision Support Systems. (IJACSA) International Journal of Advanced Computer Science and Applications.

Jumardi, A., \& Solichin, A. (2016). PROTOTIPE APLIKASI LAYANAN PENGADUAN MASYARAKAT BERBASIS ANDROID DAN WEB SERVICE. Jurnal TELEMATIKA MKOM.

Melani, Y. I. (2019). Sistem Pengaduan Layanan Akademik Menggunakan. Jurnal SISFOKOM.

Naomi, M., \& Noprisson, H. (2019). Analisa Dan Perancangan Sistem Pengaduan Mahasiswa Berbasis Web (Studi Kasus: Universitas Mercu Buana Kranggan). JUSIBI (JURNAL SISTEM INFORMASI DAN E-BISNIS).

Raharjo, B. (2019). PEMROGRAMAN ANDROID DENGAN FLUTTER. Bandung: Informatika.

Rosa \& Shalahuddin, 2013. (2013). UML, Use Case Diagram, Activity Diagram, Class Diagram. In 
Rekayasa Perangkat Lunak

Terstruktur.

Sofyan, M. R., \& Iryanti, E. (2018). APLIKASI PENANGANAN KELUHAN MAHASISWA MENGGUNAKAN. Seminar Nasional Teknologi Informasi dan Multimedia 2018.

Wattiheluw, F. H., Rochimah, S., \& Fatichah, C. (2019). KLASIFIKASI PERANGKAT LUNAK BERDASARKAN ISO/IEC 25010 MENGGUNAKAN AHP DAN FUZZY MAMDANI UNTUK SITUS WEB E-COMMERCE. JUTI Jurnal Ilmiah Teknologi Informasi.

Widianto, M. H. (2019, Desember 23). Retrieved from https://binus.ac.id/bandung/2019/1 2/algoritma-naive-bayes/

At Thaariq, Z. Z. (2021). Pengaplikasian Pembelajaran Berbasis Kehidupan Guna Mendukung Aktivitas Belajar. -, 1-12. Jurnal Inovasi Pembangunan Volume 09 No. 2

Utami, Y. T., Sofyan, R., \& Pribadi, R. I. (2021). Perancangan dan Implementasi Website Layanan Akademik di SMA Negeri 07 Bandar Lampung. -, 1-10. Jurnal Inovasi Pembangunan Volume 09 No. 2 
Halaman Kosong 